\title{
Wpływ długotrwałego oddziaływania cyklicznych zjawisk atmosferycznych na właściwości piaskowców istebniańskich
}

\author{
Beata Figarska-Warchol ${ }^{1}$, Joanna Sierakowska ${ }^{2}$
}

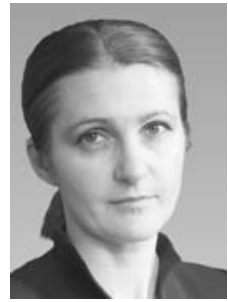

B. Figarska-Warchoł

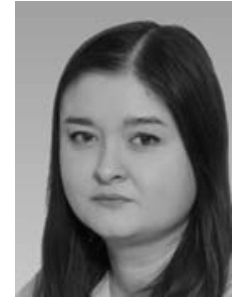

J. Sierakowska

The influence of long-term cyclic atmospheric phenomena on the Istebna sandstone properties. Prz. Geol., 69: 109-119; doi: 10.7306/2021.6

A b s t r a c t. The Istebna sandstones are one of the main stone materials used for centuries in the construction industry in Kraków and the surrounding area. It was supported not only by their decorative properties and technical parameters, but also the proximity of the outcrops. The results of research on changes in the physical and mechanical properties of samples taken from the Czastaw and Sobolów deposits are presented. They represent two structural varieties, subjected to fatigue by cyclic processes of freezing and thermal shock. Such a treatment of the samples was aimed at recreating the natural conditions in which the stone elements are subjected to the destructive effects of atmospheric phenomena associated with temperature changes during winter and summer periods. Data on the weather conditions in Krakow for the period 1951-2020 were used to assess the effect of climate on the intensity of the impact of the two above factors and, additionally, the destructive effect of rock salt, used for de-icing road surfaces. An attempt was also made to forecast the expected rate of destruction of the Istebna sandstones, based on the analysis of climate change.

Keywords: Istebna sandstones, thermal shock, physical weathering, apparent density, water absorption by weight, ultrasonic wave velocity

Piaskowce istebniańskie dolne $\mathrm{z}$ pogranicza kredy i paleocenu, będące przedmiotem zainteresowania wielu badaczy (Książkiewicz, 1951; Burtan, 1956; Kita-Badak, 1963; Unrug, 1963; Peszat, 1976; Peszat, Buczek-Pułka, 1984; Peszat, Wieser, 1999) tworzą przeważnie grube ławice o miąższości zwykle powyżej $1 \mathrm{~m}$, czasem do 4-5 m. Buduje je w przewadze gruboziarnisty materiał klastyczny (głównie kwarc i w dość dużym udziale skalenie) spojony substancją ilastą z domieszką krzemionki, rzadziej chlorytu i związków żelaza. Dosyć niska gęstość pozorna i wytrzymałość na ściskanie w połączeniu z ciepłą, szarożółtawą barwą oraz dużą blocznością tych skał sprzyjają wykorzystywaniu ich od wieków jako materiału budowlanego. W rejonie Krakowa piaskowce te były atrakcyjnym materiałem budowlanym ze względu na niewielką odległość wychodni i łatwość obróbki (Bromowicz, 2001; Rajchel, 2005; Cieszkowski, Waśkowska, 2010; Smoleńska i in., 2010; Bromowicz, Magiera, 2015), później chętnie sięgano po nie ze względu na walory dekoracyjne i możliwości uzyskiwania dużych bloków.

Kamień zastosowany w zewnętrznych elementach budowli czy mniejszych formach architektonicznych poddawany jest niszczącemu wpływowi atmosfery. Wyróżnia się przy tym dwie grupy czynników: fizyczne - wywołujące mechanicznie naprężenia wewnątrz skały, doprowadzające ją najczęściej do spękań i dezintegracji, oraz chemiczne zwykle związane z zawartymi w powietrzu zanieczyszczeniami, wchodzącymi w reakcje chemiczne ze składnikami mineralnymi (Wilczyńska-Michalik, Michalik, 1995; Wilczyńska-Michalik, 2004).

Wietrzenie fizyczne wiąże się głównie z trzema cyklicznymi zjawiskami: zamrozem, szokiem termicznym i krystalizacją soli. Pierwsze jest wywoływane przez zwię- kszającą swoją objętość wodę, zamarzającą w przestrzeni porowej skały (Halsey i in., 1998; Bromowicz, Figarska-Warchoł, 2010). W naturze odbywa się to w okresach zimowych i jest determinowane dobowymi wahaniami temperatur, między $-0,5$ a $0,5^{\circ} \mathrm{C}$. Szok termiczny jest związany z gwałtowną zmianą temperatury piaskowca, której tempo, przyjmowane $\mathrm{w}$ literaturze, musi wynosić przynajmniej $1^{\circ} \mathrm{C} / \mathrm{h}$ (Halsey $\mathrm{i}$ in., 1998), choć w praktyce laboratoryjnej jest ono znacznie wyższe. Na zjawisko to są narażone przede wszystkim elementy kamienne wyeksponowane w kierunku południowym lub zachodnim, mocno nagrzewające się w upalne dni i poddawane gwałtownemu ochłodzeniu nocą lub po nagłym opadzie deszczu.

Obecność w przestrzeni porowej soli (głównie chlorków, siarczanów i węglanów) należy do najbardziej niebezpiecznych czynników, które wpływają destrukcyjnie na strukturę skały. Ulegają one krystalizacji w wyniku przesycenia roztworów, będącego następstwem odparowania wody lub zmiany temperatury i ciśnienia. Proces ten odbywa się cyklicznie i jest związany z rozpuszczaniem fazy stałej w warunkach zwiększonej wilgotności (np. deszcz, mgła, podsiąkanie kapilarne). Ponadto naprężenia w skale mogą być powodowane także zmianą objętości soli, ulegających hydratacji lub rozszerzaniu temperaturowemu. Zatem wietrzenie solne może następować zarówno w czasie wzrostu wilgotności, jak i jej spadku oraz w trakcie podnoszenia i obniżania się temperatury powietrza (Robertson, 1988; Rembiś, Smoleńska, 2010).

Celem przeprowadzonych badań było określenie tempa oraz stopnia mechanicznego zniszczenia piaskowców istebniańskich poprzez laboratoryjne pomiary zmian właściwości fizyczno-mechanicznych, zachodzących pod

\footnotetext{
${ }^{1}$ Instytut Gospodarki Surowcami Mineralnymi i Energią PAN, ul. Józefa Wybickiego 7A, 31-261 Kraków; figarska@min-pan.krakow.pl

${ }^{2}$ AGH Akademia Górniczo-Hutnicza, al. Adama Mickiewicza 30,30-059 Kraków; sierakowska@agh.edu.pl
} 


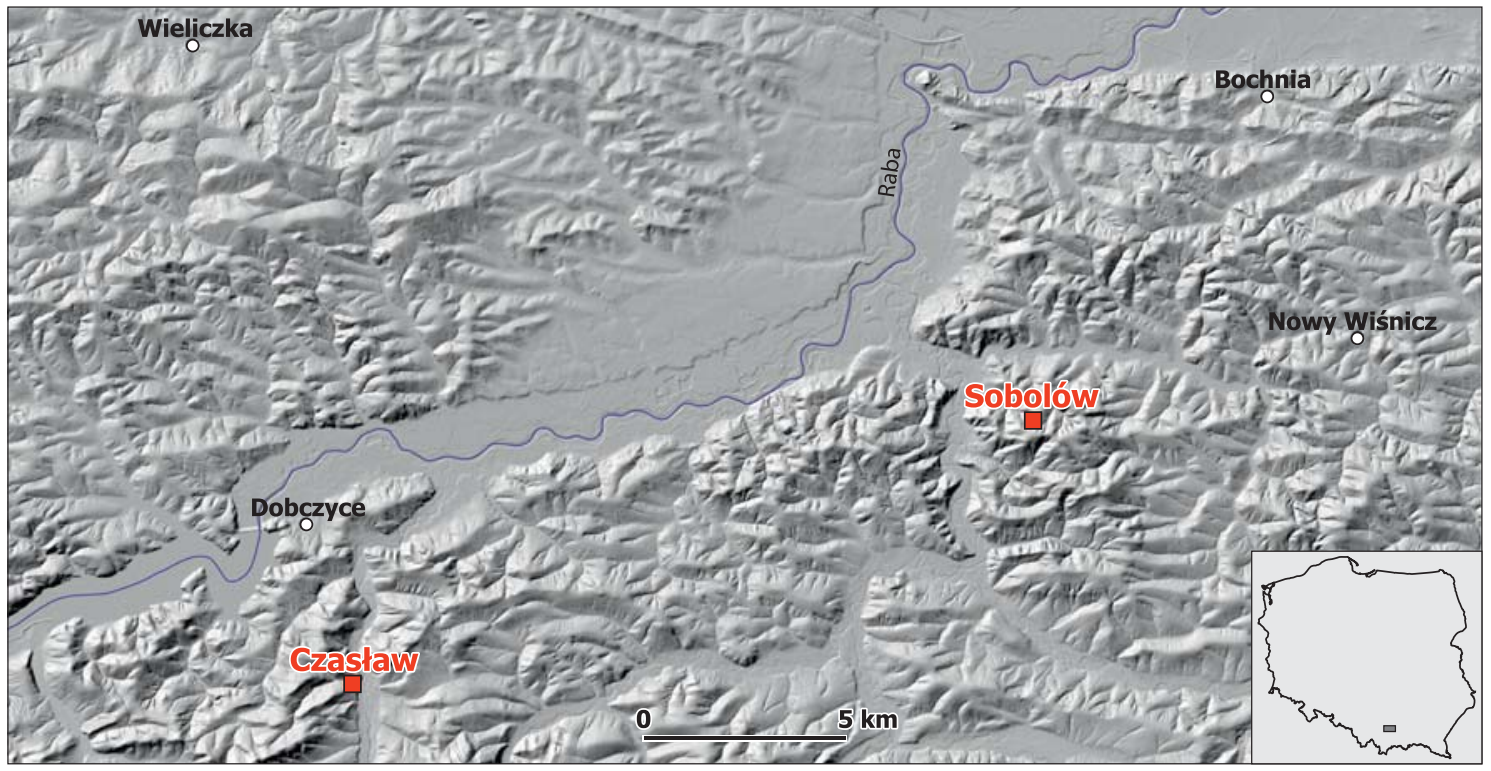

Ryc. 1. Lokalizacja geograficzna miejsc pobrania próbek do badań (mapy.geoportal.gov.pl; geolog.pgi.gov.pl)

Fig. 1. Geographical location of sampling sites (mapy.geoportal.gov.pl; geolog.pgi.gov.pl)

wpływem czynników, odzwierciedlających naturalne zjawiska pogodowe tj. zamróz i szok termiczny. Na podstawie wieloletnich danych meteorologicznych podjęto także próbę oceny wpływu zmian klimatycznych na intensywność powyższych procesów oraz, dodatkowo, na możliwość destrukcji tych piaskowców przez gromadzący się w nich chlorek sodu, stosowany do odladzania dróg i chodników.

\section{MATERIAL}

Materiał do badań pobrano z dwóch złóż piaskowców istebniańskich: Czasław (pow. myślenicki, N: 4950'32" E: $\left.20^{\circ} 06^{\prime} 55^{\prime \prime}\right)$ i Sobolów (pow. bocheński, N: 4953'53" E: $\left.20^{\circ} 21^{\prime} 00^{\prime \prime}\right)$, położonych w odległości ok. 30-35 km od centrum Krakowa w kierunku SE (ryc. 1). Znajdują się one w obrębie jednostki śląskiej, na obszarze rozległych wychodni warstw istebniańskich, odsłaniających się na terenie Pogórza Wiśnickiego.

Obydwa złoża są zagospodarowane, ale ich eksploatacja jest prowadzona w ostatnich latach okresowo. Zarówno w jednym, jak i drugim warstwy zapadaja monoklinalnie pod niezbyt dużym kątem od kilkunastu do ok. $30^{\circ}$. Średnia miąższość serii złożowej w obu przypadkach wynosi ok. 25 m, a łupki stanowią ok. 10\%.

W każdym ze złóż pobrano zorientowane w stosunku do uławicenia próbki skalne o wadze kilkunastu kilogramów, z których wycięto sześcienne kostki o boku 5 cm (18 z materiału z Czasławia i 13 z materiału z Sobolowa), przy czym pierwsze $\mathrm{z}$ wymienionych złóż stało się źródłem gruboziarnistej odmiany badanych piaskowców, a drugie średnioziarnistej.

\section{METODYKA BADAŃ}

Badania niszczącego oddziaływania czynników atmosferycznych na piaskowce istebniańskie zastosowane w zewnętrznych partiach budowli musiały zostać przeprowadzone w warunkach laboratoryjnych, zbliżonych do naturalnych. Wobec tego sposób oceny oparto zasadniczo na metodach oznaczania mrozoodporności kamienia naturalnego, a także starzenia spowodowanego szokiem termicznym, opisanych odpowiednio w normach PN-EN 12371:2010 i PN-EN 14066:2013-07. Zaproponowano przy tym pewne modyfikacje, dostosowując sposób wykonania badań m.in. do ilości dostępnego materiału skalnego, a także do celu analizy.

Proces mechanicznego zmęczenia piaskowców, odpowiadający oddziaływaniu powtarzających się wielokrotnie zjawisk pogodowych, przeprowadzono na dwa sposoby. Pierwszy polegał na poddaniu materiału skalnego 30 cyklom szoku termicznego. Wybrane próbki ogrzewano do temperatury $105^{\circ} \mathrm{C}$, utrzymując ją przez $18 \mathrm{~h}$, a następnie natychmiastowo zanurzano je całkowicie w wodzie o temperaturze pokojowej (ok. $\left.20^{\circ} \mathrm{C}\right)$ i pozostawiano na ok. $6 \mathrm{~h}$. Drugim sposobem było wywołanie powtarzających się naprężeń poprzez 30 -krotne zamrażanie w temperaturze $-20^{\circ} \mathrm{C}$ przez minimum $4 \mathrm{~h}$ nasyconych wodą próbek, a następnie ich rozmrażanie w wodzie o temperaturze pokojowej i utrzymywanie $\mathrm{w}$ zanurzeniu przez minimum $4 \mathrm{~h}$ od czasu ustabilizowania się stałej temperatury wody $20^{\circ} \mathrm{C}$. Do każdego $\mathrm{z}$ dwóch procesów niszczenia wybrano po cztery próbki z każdego złoża, pozbawione widocznych pęknięć i wykazujące wzajemnie podobieństwo wykształcenia.

Ocena wywołanych $\mathrm{w}$ materiale kamiennym zmian była oparta na porównaniu wyników obserwacji makroi mikroskopowych, a także wybranych właściwości fizyczno-mechanicznych próbek w stanie świeżym, po mrożeniu oraz po szoku termicznym. Obserwacje makroskopowe objęły wszystkie regularne próbki, poddane męczeniu, natomiast do obserwacji mikroskopowych wytypowano sześć próbek (w trzech stanach dla obydwu złóż), z których zostały sporządzone płytki cienkie. Szlify mikroskopowe wykonano w płaszczyznach prostopadłych do uławicenia.

Badania mikroskopowe wykonano najpierw z użyciem mikroskopu polaryzacyjnego do światła przechodzącego na szlifach, sporządzonych z wykorzystaniem niebieskiej żywicy epoksydowej. W skład tych badań wchodziło rozpoznanie i charakterystyka wykształcenia składników ziarnowych piaskowca, określenie ich udziału objętościowego i ilości spoiwa, a także ocena wielkości ziaren mineralnych. Zarówno analizę ilościową, jak i granulometrię prze- 


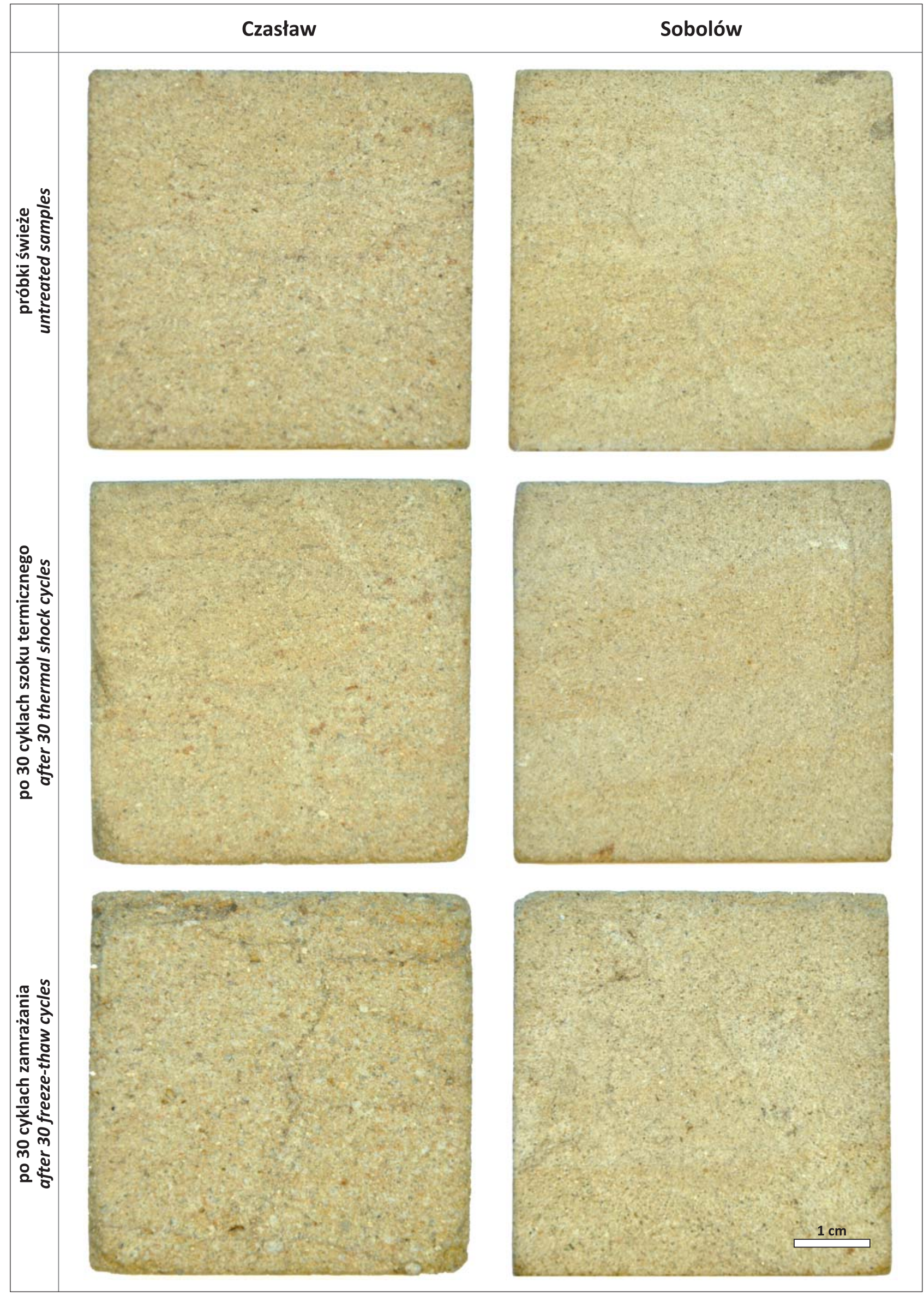

Ryc. 2. Próbki piaskowca istebniańskiego ze złóż Czasław i Sobolów: świeże, po 30 cyklach szoku termicznego i 30 cyklach zamrażania Fig. 2. Samples of the Istebna sandstones from the Czasław and Sobolów deposits in a sequence: untreated, after 30 thermal shock cycles, after 30 freeze-thaw cycles 
prowadzono wzdłuż linii pomiarowych oddalonych od siebie o ok. $3 \mathrm{~mm}$, dokonując na szlifach po ok. 300 oznaczeń i pomiarów. Szlify odkryte, wykonane z użyciem zawiesiny diamentowej, poddano obserwacjom w elektronowym mikroskopie scaningowym FEI Quanta 200 FEG za pomocą detektora EDS w celu identyfikacji składników skały.

Oznaczenia gęstości pozornej i nasiąkliwości wagowej materiału w stanie świeżym i po zmęczeniu wykonano dla wszystkich próbek poddawanych cyklicznym procesom, stosując zasady opisane w normach PN-EN 1936:2010 i PN-EN 13755:2008. Korzystając z wyników tych pomiarów, wyznaczono również postępujący ubytek masy dla próbek w stanie suchym.

Pomiar prędkości rozchodzenia się ultradźwięków, wykonywany na podstawie normy PN-EN 14579:2005, polegał na generowaniu i odbieraniu impulsów drgań podłużnych o częstotliwości $500 \mathrm{MHz}$ przy użyciu elektrostatycznych głowic nadawczej i odbiorczej, umieszczanych na przeciwległych ścianach badanych próbek, kolejno w trzech wzajemnie prostopadłych do siebie kierunkach (A i B - równolegle do uławicenia, $\mathrm{C}$ - prostopadle do uławicenia). Mierzony czas przejścia impulsu drogi o znanej długości (wymiar próbki) pozwalał na obliczenie prędkości propagacji fali.

Ze względu na istotny wpływ czynników atmosferycznych na zachowanie się kamieni w budowlach przeprowadzono także analizę zjawisk pogodowych w dłuższym okresie. Skorzystano z danych meteorologicznych udostępnionych przez Instytut Meteorologii i Gospodarki Wodnej - Państwowy Instytut Badawczy, zamieszczonych w serwisie meteomodel.pl. Wybrano dane ze stacji meteorologicznej przy Collegium Śniadeckiego UJ - dawnej siedzibie Obserwatorium Astronomicznego (ul. Kopernika 27) w Krakowie gromadzone w latach 1951-2020. Klimat w tym miejscu można odnieść do warunków, w jakich znajdują się zewnętrzne elewacje budowli Krakowa.

Na podstawie wstępnej analizy, wykonanej z użyciem danych miesięcznych i rocznych z podanego wyżej przedziału, do dalszych, szczegółowych badań wybrano dane dobowe z 25 lat. Wartości średnie temperatury rocznej były obliczane jako średnie arytmetyczne ze średnich tempera- tur miesięcznych, zaś do obliczeń średnich temperatur okresów letnich i zimowych wybierano odpowiednio dane od czerwca do sierpnia i od grudnia do lutego. Inne parametry zliczano z danych ze wszystkich dni roku. Za upalne dni przyjęto takie, w których temperatura powietrza przekraczała $28^{\circ} \mathrm{C}$. Natomiast, jeśli występowały wówczas opady deszczu, to uznawano je za epizody związane z szokiem termicznym. Z analizą intensywności działania zamrozu wiązała się konieczność zgromadzenia danych dotyczących liczby dni w roku z ujemną temperaturą przy gruncie i na wysokości klatki meteorologicznej (ok. 2 m). Szczególnie ważna była informacja na temat liczby cykli zamrażania/rozmrażania, za które uważa się zdarzenia polegające na wystapieniu temperatur dodatnich po okresie obniżenia temperatury poniżej $0^{\circ} \mathrm{C}$.

Problem wpływu zjawisk pogodowych na fizyczne wietrzenie solne, związane z naprężeniami wywołanymi krystalizacją, hydratacją lub termiczną ekspansją soli, jest bardzo złożony. Zależy on bowiem od składu chemicznego i stężenia roztworów znajdujących się w przestrzeni porowej skały, temperatury, ciśnienia i wilgotności powietrza. Ponadto dwa pierwsze z wymienionych czynników zmieniają się także wraz z poziomem zanieczyszczeń atmosfery czy lokalizacją elementu kamiennego (strony świata, wysokość nad poziomem gruntu, osłonięcie przed deszczem itp.). Dlatego analizę tych zjawisk ograniczono jedynie do oceny zmian liczby dni z opadami śniegu, co powiązano z ilością chlorku sodu zużywanego do odladzania nawierzchni chodników i tym samym mogącego się dostać do wnętrza zastosowanych w architekturze piaskowców istebniańskich. Pominięto także analizy laboratoryjne związane z tym zagadnieniem, pozostawiając je do dalszych badań.

\section{OBSERWACJE PETROGRAFICZNE}

Próbki poddane badaniom reprezentują dwie odmiany strukturalne piaskowców istebniańskich: gruboziarnistą ze złoża Czasław, i średnioziarnistą - ze złoża Sobolów. Obie skały charakteryzują się jasną szarożółtawą barwą z zaznaczającymi się delikatnie rdzawymi smugami (ryc. 2). Piaskowce z Czasławia mają raczej bezładną teksturę, ze słabo widoczną laminacją płaską. Natomiast w próbkach

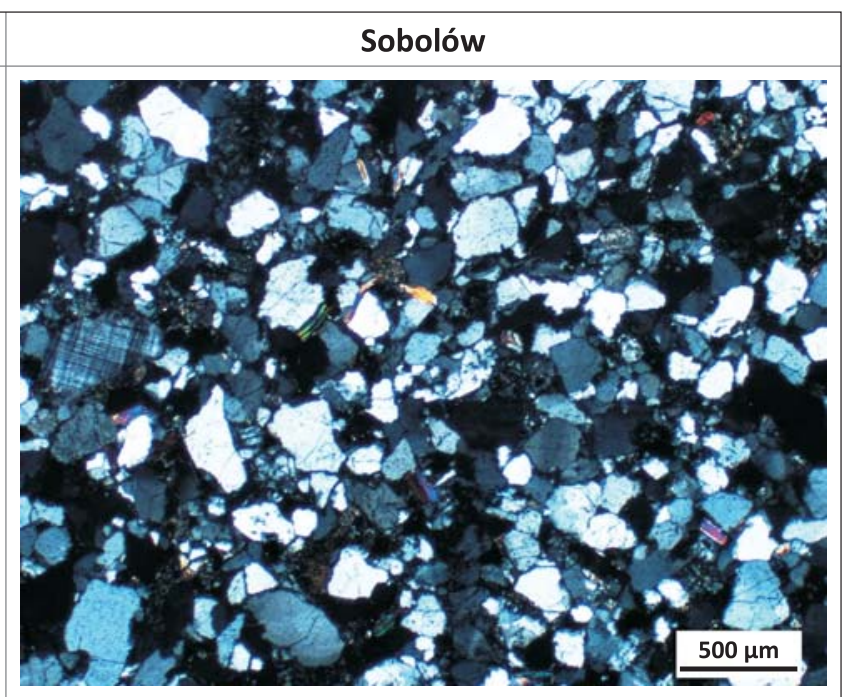

Ryc. 3. Obrazy mikroskopowe próbek piaskowca istebniańskiego ze złóż Czasław i Sobolów. Polaryzatory skrzyżowane

Fig. 3. Microphotographs of the Istebna sandstone samples from the Czasław and Sobolów deposits. Transmitted light, crossed polarisers 


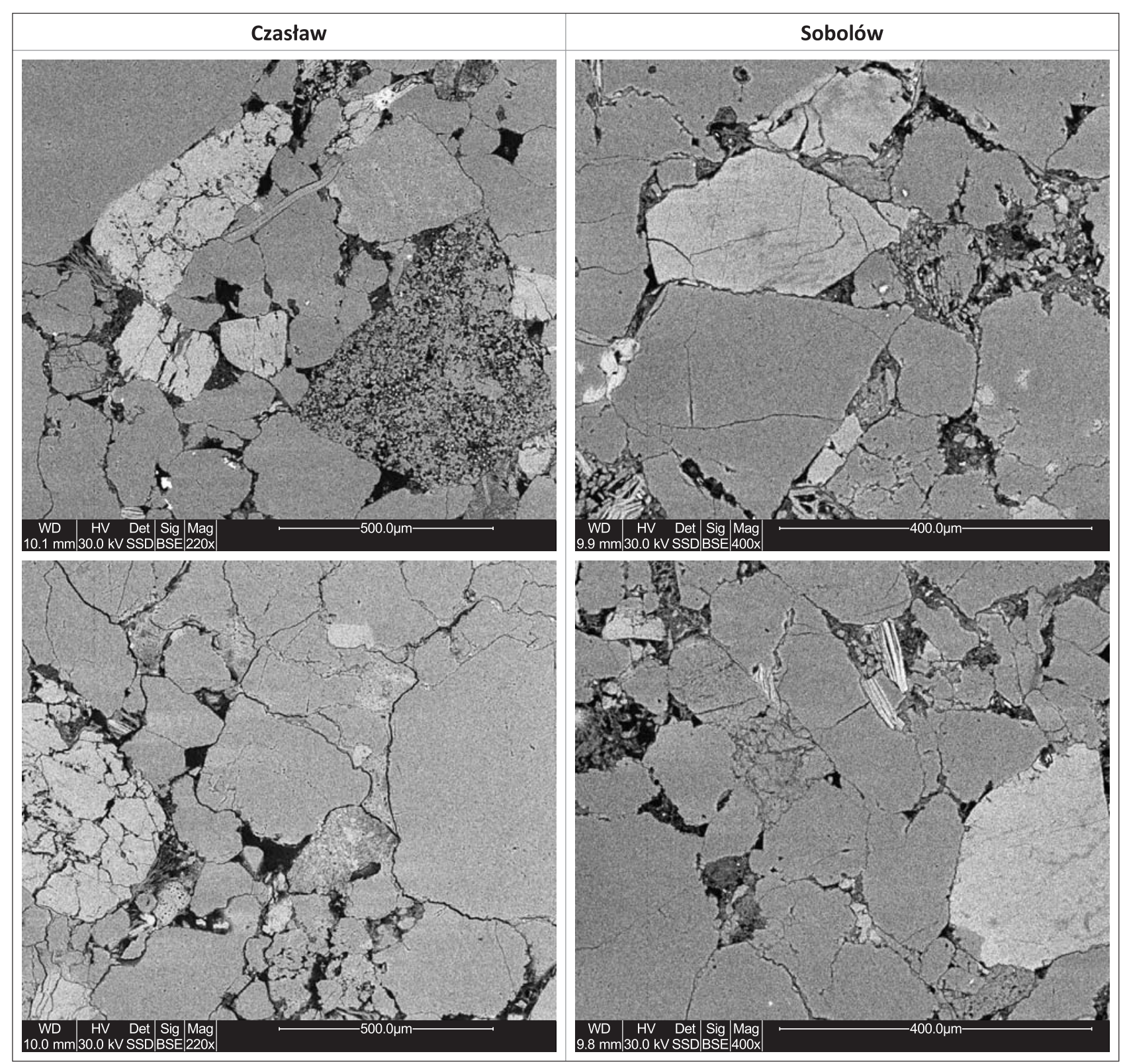

Ryc. 4. Obrazy ze skaningowego mikroskopu elektronowego (SEM) próbek piaskowca istebniańskiego ze złóż Czasław i Sobolów poddanych 30 cyklom zamrażania i rozmrażania

Fig. 4. Scanning electron microscope (SEM) images of the Istebna sandstone samples from the Czasław and Sobolów deposits after 30 freeze-thaw cycles

z Sobolowa oprócz płaskiej laminacji są obecne cienkie, ciemnoszare smugi, które podkreślają warstwowanie przekątne rynnowe. Na powierzchniach równoległych do uławicenia skał tej drugiej odmiany można zaobserwować blaszki mik o niewielkich rozmiarach (ok. $1 \mathrm{~mm}$ długości).

Obserwacje mikroskopowe w świetle przechodzącym (ryc. 3), potwierdzone później w obrazach ze skaningowego mikroskopu elektronowego (SEM) (ryc. 4), wykazały, że skład mineralno-petrograficzny obu odmian jest bardzo zbliżony (tab. 1). Dominuje kwarc w udziale ok. 60\%, a towarzyszą mu w ilościach po kilkanaście procent okruchy skał obcych (głównie krzemionkowych, rzadziej wylewnych, granitoidów i łupków łyszczykowych) oraz skalenie o różnym stopniu zachowania (głównie potasowe). Znaczącym składnikiem są też łyszczyki, obecne w ilości ok. $1 \% \mathrm{w}$ piaskowcu z Czasławia i ponad 4\% w próbkach z Sobolowa. Sporadycznie występują agregaty glaukonitu. Ilasto-krzemionkowe spoiwo o charakterze kontaktowo- -porowym stanowi ok. 9\% objętości piaskowca z Czasławia i $11 \%$ - piaskowca z Sobolowa. Krzemionka występuje zwykle w formie drobnych agregatów kwarcowych, rzadko tworząc cienkie obwódki regeneracyjne. Ciemnoszare smugi, widoczne makroskopowo zwłaszcza w próbkach z Sobolowa, są nagromadzeniami nieprzeźroczystej substancji, prawdopodobnie organicznego pochodzenia i związków żelaza. Tworzą one laminy o grubości do kilku milimetrów, które odznaczają się także drobniejszym uziarnieniem.

Frakcja ziaren jest znacząco większa w próbkach z Czasławia (ryc. 3) i generalnie piaskowce tej odmiany są słabo wysortowane. Kwarc osiaga rozmiary do 1,5 mm, a okruchy skał 1,3 mm, podczas gdy w próbkach z Sobolowa wielkość tych składników nie przekracza $1 \mathrm{~mm}$ (tab. 1). Największe ziarna skaleni są także dwukrotnie większe w Czasławiu niż w Sobolowie. Jedynie blaszki łyszczyków mają porównywalne długości. 
Tab. 1. Skład mineralno-petrograficzny próbek piaskowców ze złóż Czasław i Sobolów

Table 1. Mineral and petrographic composition of the sandstone samples from the Czasław and Sobolów deposits

\begin{tabular}{|l|c|c|c|c|}
\hline & \multicolumn{2}{|c|}{ Czaslaw } & \multicolumn{2}{c|}{ Sobolów } \\
\hline $\begin{array}{c}\text { Skladnik ziarnowy } \\
\text { Grain component }\end{array}$ & $\begin{array}{c}\text { Udzial [\%] } \\
\text { Grain content [\%] }\end{array}$ & $\begin{array}{c}\text { Rozmiar ziarna [mm] } \\
\text { Grain size [mm] }\end{array}$ & $\begin{array}{c}\text { Udzial [\%] } \\
\text { Grain content [\%] }\end{array}$ & $\begin{array}{c}\text { Rozmiar ziarna [mm] } \\
\text { Grain size [mm] }\end{array}$ \\
\hline Kwarc / Quartz & 61,3 & $0,09-1,58$ & 58,3 & $0,19-0,73$ \\
\hline Okruchy skał / Rock fragments & 15,0 & $0,25-1,26$ & 13,3 & $0,14-0,82$ \\
\hline Skalenie / Feldspars & 13,0 & $0,09-0,64$ & 12,0 & $0,07-0,25$ \\
\hline Lyszczyki / Micas & 1,1 & $0,06-0,52$ & 4,4 & $0,09-0,63$ \\
\hline Glaukonit / Glauconite & 0,3 & $0,08-0,27$ & 0,7 & $0,14-0,27$ \\
\hline Spoiwo / Cement & 9,3 & - & 11,3 & - \\
\hline
\end{tabular}

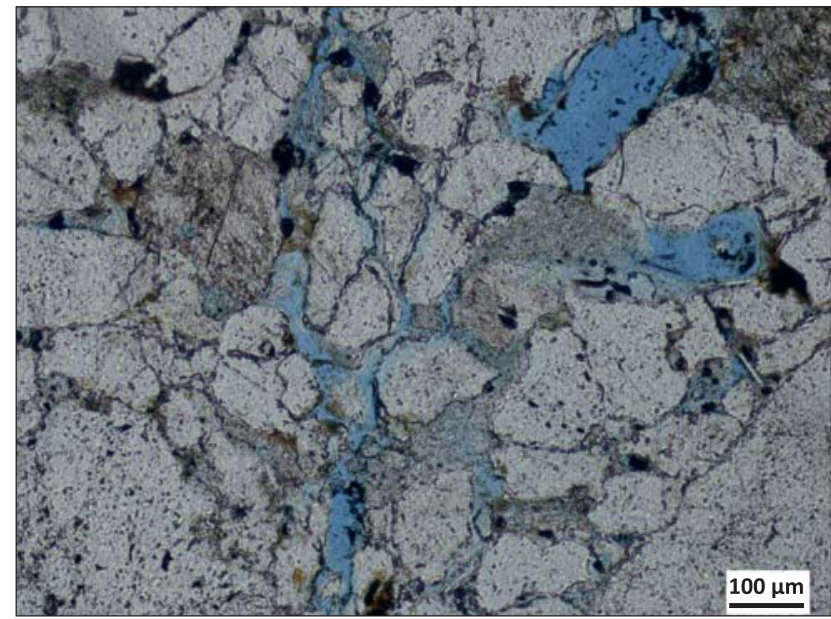

Ryc. 6. Spękania powstałe w próbce piaskowca istebniańskiego ze złoża Czasław poddanej 30 cyklom zamrażania i rozmrażania. Porowatość podkreślona niebieską barwą żywicy. Polaryzatory równoległe

Fig. 6. Fractures in a sample of the Istebna sandstone from the Czasław deposit, generated after 30 freeze-thaw cycles. Sample porosity is expressed in blue resin. Transmitted light, one polarizer

Przeważający ilościowo kwarc w próbkach z Czasławia reprezentują głównie osobniki monokrystaliczne o prostym, rzadziej falistym i mozaikowym ściemnianiu, zwykle spękane, z wrostkami i inkluzjami. Jego ziarna, a także okruchy skał obcych i skalenie są dość dobrze obtoczone i ściśle upakowane, przez co dominują między nimi wypukło-wklęsłe i proste kontakty. Zazębianie się ziaren jest znacznie rzadsze niż w piaskowcach z Sobolowa, w których kwarc i towarzyszące mu składniki są zwykle ostrokrawędziste, a stopień upakowania podobny (ryc. 4).

Pierwsze makroskopowe oznaki wpływu niszczącego oddziaływania szoku termicznego i zamrozu zaobserwowano dopiero po kilkunastu cyklach obu tych procesów (ok. 11-12 cykl dla Czasławia i 13-15 dla Sobolowa), w postaci kruszenia się próbek na krawędziach i osadzania rozluźnionego materiału na dnie naczynia z wodą. Po 30 cyklach próbki z Sobolowa wykazywały jedynie niewielkie zaokrąglenia krawędzi i naroży bez względu na metodę męczenia, jakiej były poddane (ryc. 2). Piaskowce z Czasławia po 30 cyklach szoku termicznego miały nieco bardziej zaokraglone krawędzie, choć ogólnie ich stan był nadal dobry, podczas gdy po 30 cyklach zamrozu widoczne były w nich drobne pęknięcia, a nawet odspojenia fragmentów.

Obserwacje mikroskopowe nie pozwoliły na wykazanie wpływu męczenia na próbki z Sobolowa. Natomiast w szlifach piaskowców z Czasławia poddanych zamrozowi zaobserwowano zwiększający się udział drobnych porów (ryc. 5 - niebieski kolor - patrz str. 68) zarówno w brzeżnych, jak i w głębszych partiach próbek już po 20 cyklach tego procesu. Po 30 cyklach niektóre z porów zaczęły się ze sobą łączyć, tworząc spękania, zwłaszcza w kilkumilimetrowej zewnętrznej strefie (ryc. 6). Obrazy z SEM okazały się mało przydatne w analizie porównawczej próbek w różnym stanie zmęczenia.

\section{WŁAŚCIWOŚCI FIZYCZNE}

Wyjściowe właściwości fizyczne obu odmian piaskowców są do siebie zbliżone. Piaskowce z Czasławia przy średniej gęstości pozornej $2,32 \mathrm{~g} / \mathrm{cm}^{3}$, charakteryzowały się nasiąkliwością wagową $4,26 \%$, podczas gdy wartości tych parametrów dla próbek z Sobolowa wynosiły odpowiednio $2,30 \mathrm{~g} / \mathrm{cm}^{3}$ i 4,59\%. Współczynniki zmienności tych parametrów są niewielkie - ok. 1\% dla gęstości pozornej i kilka procent dla nasiąkliwości wagowej.

Proces męczenia poprzez szok termiczny nie spowodował znaczących zmian wartości omawianych właściwości (ryc. 7). Stwierdzone zmiany można przypisać w większości niedokładnościom pomiarowym. Natomiast cykliczne zamrażanie próbek dopiero po 30 cyklach doprowadziło do istotnych zmian, szczególnie w odniesieniu do nasiąkliwości. Jej średnia wartość wzrosła wówczas dla próbek z Czasławia do 4,75\%, a dla próbek z Sobolowa do 4,79\%. Stosowane procedury męczenia, zwłaszcza po 30 cyklach, wywarły nieco wyraźniejszy wpływ na ubytek masy (ryc. 8), który wiązał się głównie z wykruszaniem ziaren na krawędziach. Również ten parametr wskazuje większą podatność na niszczenie próbek z Czasławia.

\section{PRĘDKOŚĆ PODLUŻNYCH FAL ULTRADŹWIĘKOWYCH}

Najbardziej czułym badaniem wykrywającym zmiany, jakie zachodzą pod wpływem mechanicznego niszczenia badanych skał, są pomiary prędkości podłużnych fal ultradźwiękowych. Obniżenie tej prędkości odnotowano w obu odmianach piaskowców istebniańskich już po 10 cyklach obu sposobów męczenia (ryc. 9). Szok termiczny spowodował zmianę prędkości nasyconych wodą próbek z Czasławia od wartości 2,13 do $1,94 \mathrm{~km} / \mathrm{s}$, a z Sobolowa - od 2,49 do $2,20 \mathrm{~km} / \mathrm{s}$ po 30 cyklach. W przypadku mrożenia uzyskane wyniki wskazują na bardzo wyraźny spadek prędkości dla gruboziarnistych piaskowców ze złoża Czasław (z 2,02 do 1,50 km/s). Odpowiednio dla piaskowców z Sobolowa był to spadek z 2,45 do $2,17 \mathrm{~km} / \mathrm{s}$. Największe zmiany dotyczyły zawsze kierunku pomiaru prostopadłego do uławicenia (kierunek C), choć w świe- 


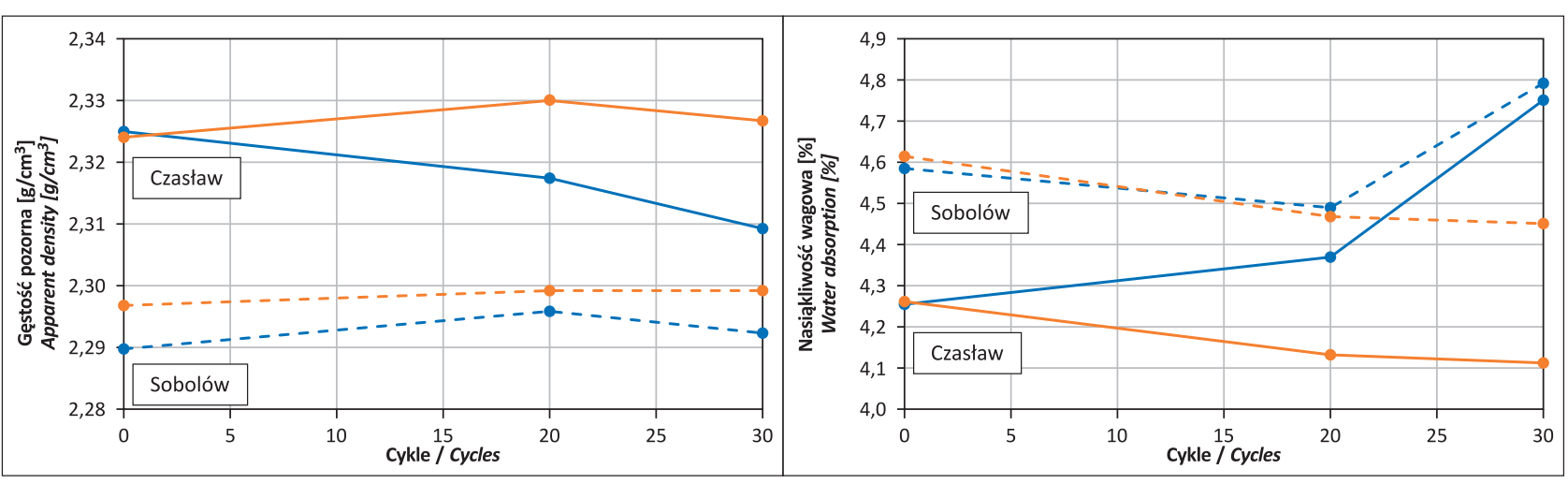

Ryc. 7. Zmiany właściwości fizycznych próbek piaskowca istebniańskiego ze złóż Czasław (linia ciagła) i Sobolów (linia przerywana) poddanych 20 i 30 cyklom szoku termicznego (pomarańczowy) oraz zamrażania (niebieski)

Fig. 7. Changes of the physical properties of the Istebna sandstones from the Czasław (solid line) and Sobolów deposit (dashed line) after their 20 and 30 cycles of thermal shock (in orange) and freezing (in blue)

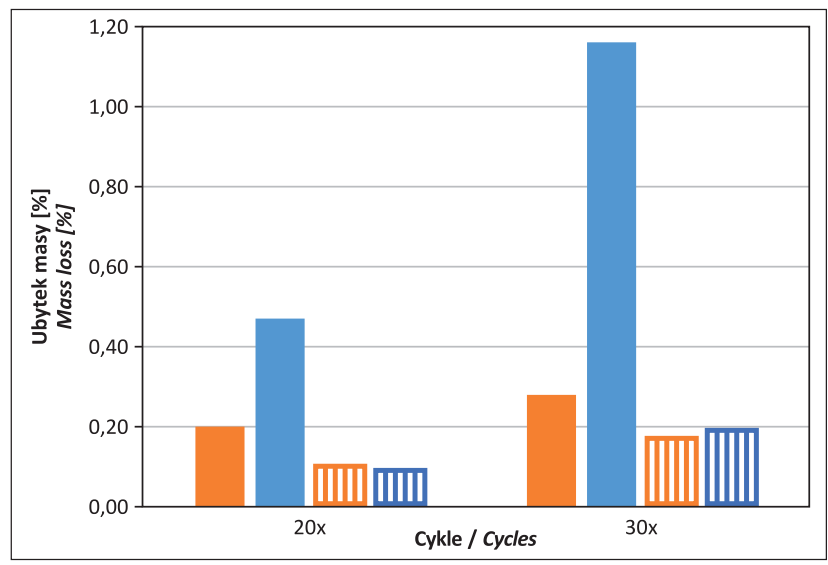

Ryc. 8. Procentowy ubytek masy suchych próbek piaskowców ze złóż Czasław (pełny) oraz Sobolów (zakreskowany) po 20 i 30 cyklach szoku termicznego (pomarańczowy) i zamrażania (niebieski)

Fig. 8. Percentage mass loss of the dry Istebna sandstone samples from the Czasław (solid) and Sobolów deposits (hatched) after their 20 and 30 cycles of thermal shock (in orange) and freezing (in blue)

żych próbkach nie zawsze reprezentował on kierunek o najniższej prędkości.

Ponadto nasycenie świeżych próbek wodą spowodowało wzrost prędkości propagacji fal dźwiękowych w stosunku do prób suchych o $0,22 \mathrm{~km} / \mathrm{s}$ w przypadku próbek z Sobolowa i tylko o $0,08 \mathrm{~km} / \mathrm{s}$ dla próbek z Czasławia.

\section{ANALIZA ZJAWISK POGODOWYCH}

Obliczenia dla okresów letnich (czerwiec-sierpień) i zimowych (grudzień-luty) oraz dla całych lat kalendarzowych w okresie 1951-2020 są podstawą do stwierdzenia, że ich średnie temperatury generalnie wzrastają od połowy lat $80 . \mathrm{XX}$ w. (ryc. 10). Uwagę zwracają znacznie większe wahania tych wartości dla zim (w latach 1952-1983 w granicach od $-7,37^{\circ} \mathrm{C}$ do $1,70^{\circ} \mathrm{C}$, a w latach $1984-2020$ od $-5,27$ do $3,07^{\circ} \mathrm{C}$ ) niż dla okresów letnich (w latach 1951-1983 w przedziale od 16,17 do $19,20^{\circ} \mathrm{C}$, w latach 1984-2020 od 16,43 do $21,23^{\circ} \mathrm{C}$ ). Aby bliżej poznać zmienność warunków pogodowych w tych skrajnie niekorzystnych dla zachowania materiału kamiennego okresach przeanalizowano dane dla poszczególnych dni z wybra- nych 25 roczników (tab. 2). I tak, zdecydowano się uwzględnić po kilka lat:

- w których okresy letnie charakteryzowały się średnią temperaturą powyżej $19^{\circ} \mathrm{C}$ (lata 1951-1953, 2002-2003, 2017-2019);

- w których średnia temperatura zimy była niższa niż $-2^{\circ} \mathrm{C}$ (lata 1963-1965, 1969-1970, 1979, 1985-1987);

- w których średnia temperatura lata była niższa niż $19^{\circ} \mathrm{C}$, a zimy wyższa niż $-2^{\circ} \mathrm{C}$ (lata 1962 , 1976-1978, 1988-1990).

Upalnym okresom letnim nie zawsze towarzyszyły ciepłe zimy. Również po mroźnych zimach następowały okresy letnie zarówno stosunkowo chłodne (np. w 1970 czy 1985 r.), jak i gorące (np. w 2003 r.). Wartości średnich temperatur okresów letnich słabo korelują z ich temperaturami maksymalnymi, ponieważ nawet w trakcie stosunkowo chłodnych okresów letnich występują, choćby nieliczne, dni upalne.

Stwierdzono natomiast bardzo wysoką korelację $\left(\mathrm{R}^{2}=\right.$ $=71,39 \%$ ) pomiędzy średnią temperaturą lata a liczbą dni o temperaturze powyżej $28^{\circ} \mathrm{C}$ oraz wysoką $\left(\mathrm{R}^{2}=63,11 \%\right)$ pomiędzy tym pierwszym parametrem a liczbą zdarzeń pogodowych, wywołujących zjawisko szoku termicznego elementów kamiennych wystawionych na działanie promieni słonecznych. Z analizy wynika, że chłodnym okresom letnim o średniej temperaturze do $17^{\circ} \mathrm{C}$, towarzyszyło tylko kilkanaście upalnych dni, z których zaledwie 3-5 kończyło się deszczem lub burzą. Z kolei w ostatnim 20-leciu temperatura latem przekraczała nieraz $36^{\circ} \mathrm{C}$, a liczba upalnych dni wynosiła aż 36-51, przy czym 13-18 z nich towarzyszyły opady, powodujące gwałtowne obniżenie temperatury powietrza. Choć brak jest dokładnych danych, by można było ocenić ten spadek tuż po takim zdarzeniu, to jednak na podstawie dziennych temperatur maksymalnych i minimalnych (te drugie notowane zwykle noca) można stwierdzić, że przykładowo latem 1952 r. po burzach, jakie miały miejsce w upalne dni, następowało ochłodzenie o $8,7-15,4^{\circ} \mathrm{C}$ (śr. o $13,4^{\circ} \mathrm{C}$ ), latem 1963 r. o $16,2-17,1^{\circ} \mathrm{C}$ (średnio o $16,7^{\circ} \mathrm{C}$ ), a latem 2018 r. o $8,7-17,9^{\circ} \mathrm{C}$ (średnio o $13,1^{\circ} \mathrm{C}$ ). Jednocześnie należy mieć na uwadze, iż gwałtowne obniżenie temperatury powierzchni piaskowca było znacznie wyższe niż powietrza, ponieważ kamień podlega silniejszemu nagrzewaniu.

Dane z wybranych lat z przedziału 2002-2019 (tab. 2) wskazują, że w pierwszym 20-leciu XXI w. klimat w okre- 


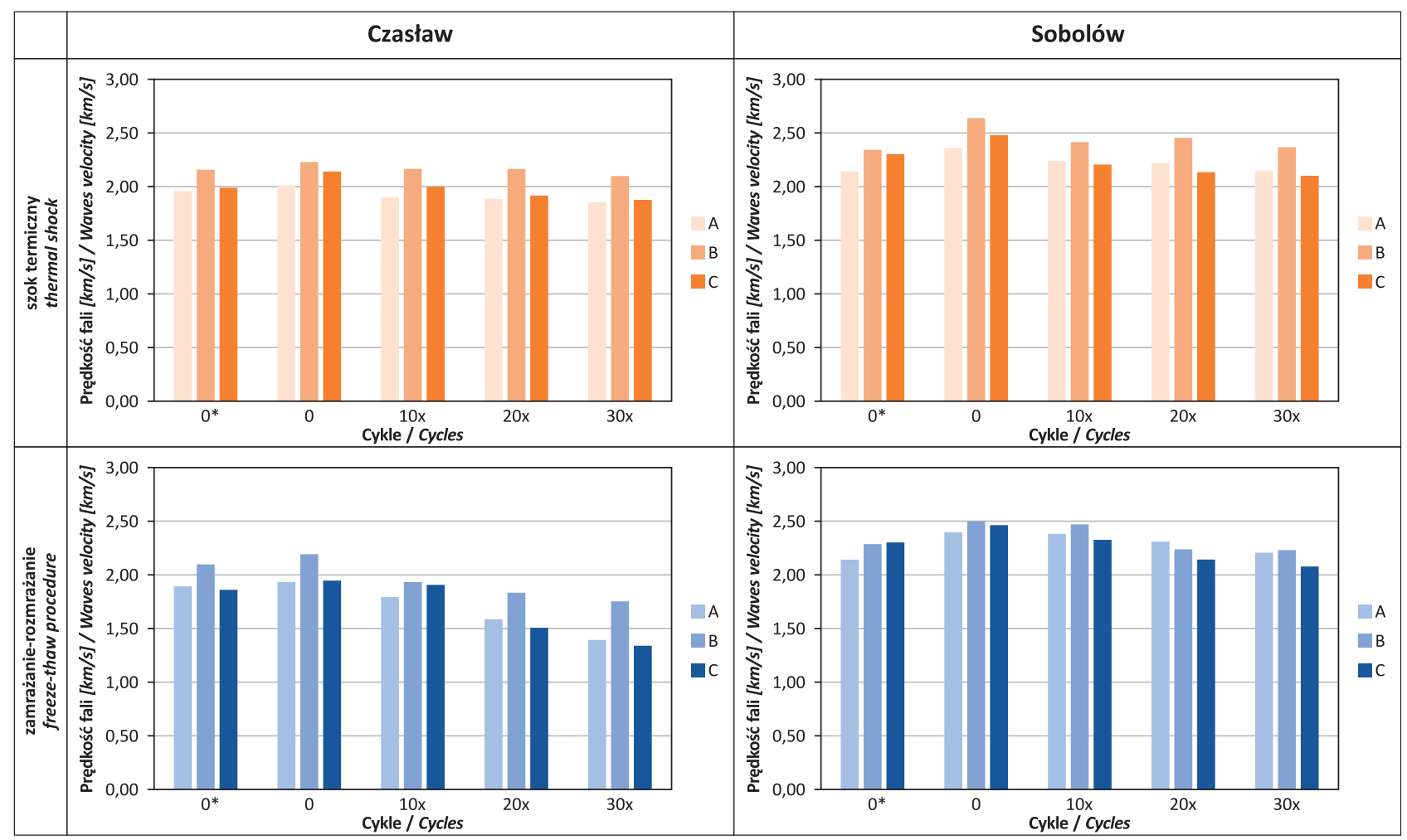

Ryc. 9. Zmiany prędkości podłużnych fal ultradźwiękowych w trzech prostopadłych kierunkach dla próbek piaskowca istebniańskiego ze złóż Czasław i Sobolów poddanych cyklicznym procesom mechanicznego męczenia. Objaśnienia: wyniki podano dla świeżych próbek w stanie suchym $-0 *$ i po nasyceniu wodą - 0 oraz dla prób nasyconych wodą po kolejnych cyklach mechanicznego męczenia $(10 \times, 20 \times, 30 \times)$

Fig. 9. The changes of the velocities of the longitudinal ultrasonic waves in three mutually perpendicular directions in the Istebna sandstone samples from the Czasław and Sobolów deposits subjected to the cyclic processes of mechanical fatigue. Explanations: the results were given for fresh samples in a dry state $-0^{*}$ and after water saturation -0 , as well as for water saturated samples after successive cycles of mechanical fatigue $(10 \times, 20 \times, 30 \times)$

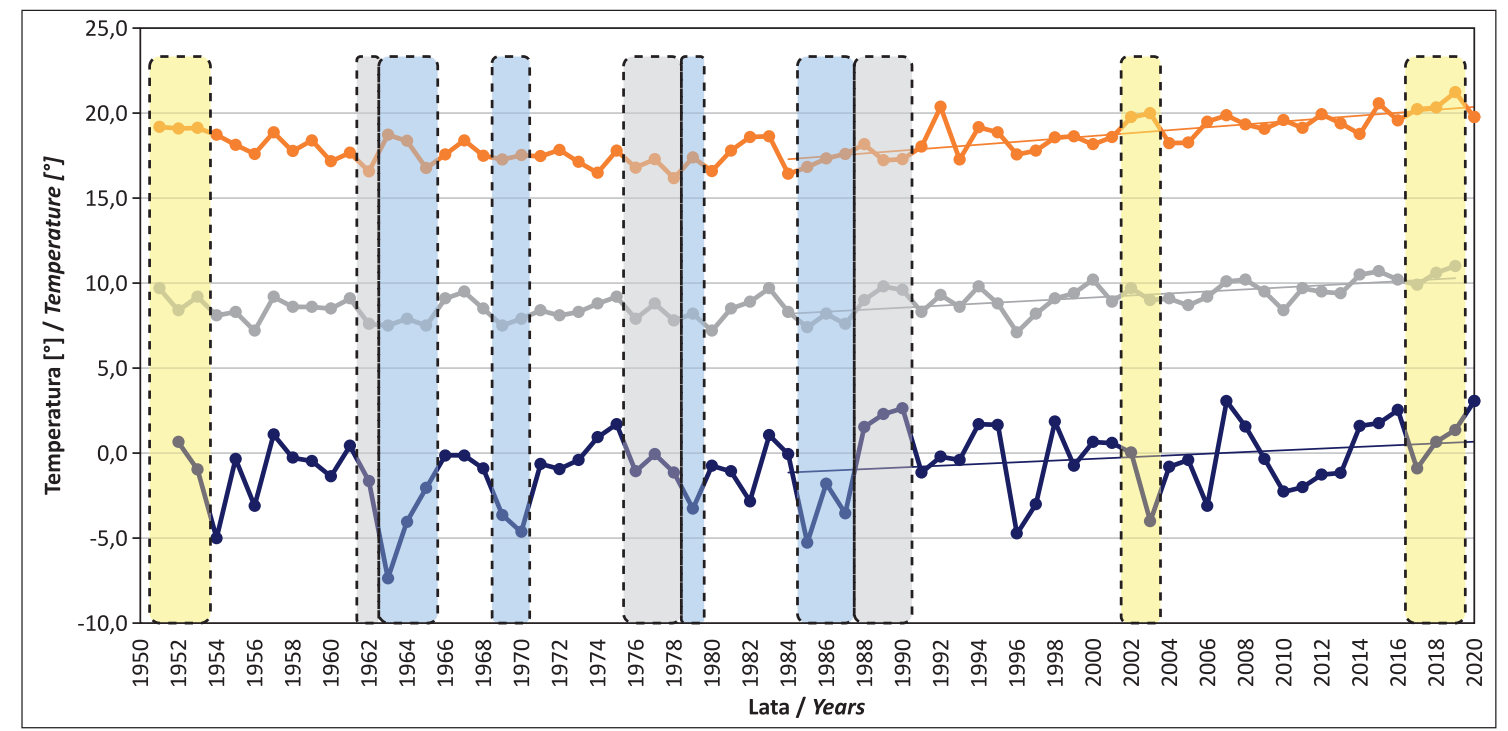

Ryc. 10. Średnie temperatury roku (szary), lata (pomarańczowy) i zimy (granatowy) w Krakowie w latach 1951-2020 z zaznaczonymi okresami wybranymi do szczegółowej analizy (żółty - okresy letnie ze średnią temp. powyżej $19^{\circ} \mathrm{C}$, niebieski - okresy zimowe ze średnią temperaturą poniżej $-2^{\circ} \mathrm{C}$, szary - okresy z przeciętnymi temp. latem i zima)

Fig. 10. Average temperatures of the year (grey), summer (orange) and winter (navy blue) in Kraków in the years 1951-2020. The periods selected to be analysed in details are marked as follows: yellow (summers with the average temperatures above $19^{\circ} \mathrm{C}$ ), blue (winters with the average temperatures below $-2^{\circ} \mathrm{C}$ ), and grey (time spans with the average temperatures in summers and winters)

sach zimowych niewiele różnił się od tego, jaki panował w Krakowie na początku lat 50. XX w. Temperatury minimalne, mierzone $2 \mathrm{~m}$ nad gruntem, zarówno wtedy, jak i w ostatnich latach wynosiły kilkanaście stopni Celsjusza poniżej zera, a ujemne temperatury powietrza panowały przez 73-112 dni. Natomiast w czasie mroźnych zim w la- 
Tab. 2. Wyniki analizy pogody w Krakowie dla wybranych lat z przedziału 1951-2020

Table 2. Analyses of the weather data in Cracow for the selected years within the period 1951-2020

\begin{tabular}{|c|c|c|c|c|c|c|c|c|c|c|c|}
\hline \multirow[b]{2}{*}{$\begin{array}{l}\text { Rok } \\
\text { Year }\end{array}$} & \multirow[b]{2}{*}{$\begin{array}{c}\text { Średnia } \\
\text { roczna } \\
\text { temp. } \\
\text { Annual } \\
\text { average } \\
\text { temp. }\end{array}$} & \multicolumn{4}{|c|}{ Lato / Summer } & \multicolumn{6}{|c|}{ Zima / Winter } \\
\hline & & $\begin{array}{c}\text { Średnia } \\
\text { temp. lata } \\
\text { (VI-VIII) } \\
\text { Summer } \\
\text { (VI-VIII) } \\
\text { average } \\
\text { temp. }\end{array}$ & $\begin{array}{l}\text { Max. } \\
\text { temp. } \\
\text { Max. } \\
\text { temp. }\end{array}$ & $\begin{array}{l}\text { Liczba } \\
\text { dni } \mathrm{z} \\
\text { temp. } \\
>28^{\circ} \mathrm{C} \\
\text { Number of } \\
\text { days with } \\
\text { temp. } \\
>28^{\circ} \mathrm{C}\end{array}$ & $\begin{array}{c}\text { Liczba } \\
\text { dni } \mathrm{z} \\
\text { temp. } \\
>28^{\circ} \mathrm{C} \\
\mathrm{i} \text { opadem } \\
\text { Number of } \\
\text { days with } \\
\text { temp. } \\
>28^{\circ} \mathrm{C} \text { and } \\
\text { rainfall }\end{array}$ & $\begin{array}{c}\text { Średnia } \\
\text { temp. } \\
\text { zimy } \\
\text { (XII-II) } \\
\text { Winter } \\
\text { (XII-II) } \\
\text { average } \\
\text { temp. }\end{array}$ & $\begin{array}{c}\text { Min. } \\
\text { temp. } \\
\text { Min. temp. }\end{array}$ & \begin{tabular}{|} 
Liczba \\
dni z \\
pokrywą \\
śnieżną \\
Number of \\
days with \\
the snow \\
cover
\end{tabular} & \begin{tabular}{|} 
Liczba \\
dni z \\
temp. \\
przy \\
gruncie \\
$<0^{\circ} \mathrm{C}$ \\
Number of \\
days with \\
temp. \\
$<0^{\circ} \mathrm{C}$ at \\
the \\
ground \\
level
\end{tabular} & $\begin{array}{c} \\
\text { Liczba } \\
\text { dni z } \\
\text { temp. } \\
<0^{\circ} \mathrm{C} \\
\text { Number of } \\
\text { days with } \\
\text { temp. } \\
<0^{\circ} \mathrm{C}\end{array}$ & $\begin{array}{c}\text { Liczba } \\
\text { dni z } \\
\text { mrozem w } \\
\text { nocy } \\
\text { i dodatnią } \\
\text { temp. } \\
\text { w dzień } \\
\text { Number of } \\
\text { days with } \\
\text { frost at } \\
\text { night and } \\
\text { day's } \\
\text { temp. } \\
>0^{\circ} \mathrm{C}\end{array}$ \\
\hline 1951 & 9,7 & 19,2 & 32,1 & 21 & 7 & b.d. & b.d. & b.d. & b.d. & b.d. & b.d. \\
\hline 1952 & 8,4 & 19,1 & 35,1 & 19 & 7 & 0,7 & $-15,1$ & 68 & b.d. & 102 & 78 \\
\hline 1953 & 9,2 & 19,1 & 32,1 & 15 & 6 & $-1,0$ & $-15,4$ & 73 & b.d. & 101 & 67 \\
\hline 1962 & 7,6 & 16,6 & 33,0 & 14 & 5 & $-1,6$ & $-25,7$ & 89 & 145 & 102 & 61 \\
\hline 1963 & 7,5 & 18,7 & 34,7 & 17 & 3 & $-7,4$ & $-26,8$ & 102 & 155 & 131 & 63 \\
\hline 1964 & 7,9 & 18,4 & 33,2 & 24 & 5 & $-4,0$ & $-16,9$ & 96 & 137 & 118 & 57 \\
\hline 1965 & 7,5 & 16,8 & 33,1 & 12 & 3 & $-2,0$ & $-22,6$ & 86 & 146 & 111 & 73 \\
\hline 1969 & 7,5 & 17,3 & 32,0 & 20 & 4 & $-3,6$ & $-19,5$ & 71 & 163 & 130 & 78 \\
\hline 1970 & 7,9 & 17,5 & 31,7 & 8 & 1 & $-4,6$ & $-20,0$ & 111 & 165 & 118 & 59 \\
\hline 1976 & 7,9 & 16,8 & 33,5 & 15 & 3 & $-1,1$ & $-18,9$ & 67 & 150 & 105 & 68 \\
\hline 1977 & 8,8 & 17,3 & 31,3 & 17 & 2 & $-0,1$ & $-13,9$ & 77 & 142 & 92 & 65 \\
\hline 1978 & 7,8 & 16,2 & 30,5 & 10 & 4 & $-1,1$ & $-14,6$ & 52 & 166 & 96 & 68 \\
\hline 1979 & 8,2 & 17,4 & 31,5 & 23 & 5 & $-3,3$ & $-17,8$ & 99 & 155 & 104 & 57 \\
\hline 1985 & 7,4 & 16,8 & 32,9 & 16 & 5 & $-5,3$ & $-23,1$ & 69 & 154 & 115 & 57 \\
\hline 1986 & 8,2 & 17,3 & 32,6 & 19 & 5 & $-1,8$ & $-22,1$ & 78 & 151 & 113 & 62 \\
\hline 1987 & 7,6 & 17,6 & 32,4 & 20 & 13 & $-3,5$ & $-26,1$ & 77 & 159 & 104 & 54 \\
\hline 1988 & 9,0 & 18,2 & 34,5 & 24 & 7 & 1,5 & $-13,0$ & 37 & 143 & 84 & 74 \\
\hline 1989 & 9,8 & 17,2 & 33,8 & 14 & 4 & 2,3 & $-15,2$ & 22 & 117 & 83 & 74 \\
\hline 1990 & 9,6 & 17,3 & 32,3 & 20 & 6 & 2,6 & $-12,3$ & 22 & 115 & 76 & 60 \\
\hline 2002 & 9,7 & 19,8 & 32,8 & 39 & 13 & 0,0 & $-19,0$ & 61 & 132 & 91 & 59 \\
\hline 2003 & 9,0 & 20,0 & 33,4 & 44 & 15 & $-4,0$ & $-18,6$ & 74 & 141 & 112 & 68 \\
\hline 2017 & 9,9 & 20,2 & 36,7 & 36 & 14 & $-0,9$ & $-20,0$ & 47 & 114 & 85 & 64 \\
\hline 2018 & 10,6 & 20,3 & 33,7 & 51 & 18 & 0,7 & $-15,9$ & 38 & 122 & 84 & 62 \\
\hline 2019 & 11,0 & 21,2 & 36,3 & 45 & 15 & 1,4 & $-11,0$ & 25 & 108 & 73 & 58 \\
\hline 2020 & b.d. & 19,8 & 32,6 & 36 & 17 & 3,1 & $-6,0$ & 1 & 125 & 64 & 64 \\
\hline
\end{tabular}

tach 60. czy 80. XX w. przez 104-131 dni temperatura powietrza spadała poniżej zera. Jej minimalne wartości często były niższe niż $-20^{\circ} \mathrm{C}$, dochodząc nieraz poniżej $-26^{\circ} \mathrm{C}$. Temperatura mierzona przy gruncie bywa zwykle niższa, dlatego we wcześniejszych latach jej ujemne wartości w czasie zimy notowano przez ok. 140-170 dni, natomiast w XXI w. było to już tylko ok. 110-140 dni.

Z uzyskanych danych wynika, że liczba cykli mrozu/odwilży na przestrzeni analizowanych kilkudziesięciu lat mieściła się w granicach 54-78, i wydaje się, nie zależała od temperatury średniej lub minimalnej okresu zimowego. Jednak w czasie łagodnych zim cykle takie występowały w okresie listopad-marzec najczęściej w dobowych odstępach, a obniżenie temperatury powietrza nocą sięgało zwykle co najwyżej minus kilku ${ }^{\circ} \mathrm{C}$, podczas gdy w chłodne zimy okresy kilkunastostopniowego mrozu utrzymywały się nieraz przez wiele dni lub tygodni i były rozdzielane stosunkowo krótkimi okresami odwilży. Często wówczas jeszcze w kwietniu lub w maju zdarzały się epizody krótkotrwałego ochłodzenia poniżej $0^{\circ} \mathrm{C}$.

Średnia temperatura okresu zimowego dobrze koreluje z liczbą dni z obecnością pokrywy śnieżnej $\left(R^{2}=69,52 \%\right)$, przy czym od końca lat 80 . XX w. nastąpił znaczny spadek tej liczby. Wcześniej, w czasie mroźnych zim było to 69111 śnieżnych dni, a w innych latach 52-89, natomiast w latach 1988-2019 śnieg utrzymywał się przez 22-74 dni i tylko przez 1(!) dzień w okresie zimowym z przełomu lat 2019/2020.

\section{DYSKUSJA}

Wśród zjawisk atmosferycznych, mających wpływ na fizyczne wietrzenie piaskowców istebniańskich, powtarzające się cykle zamarzania i odmarzania wody zawartej w porach wywołują bardziej intensywne zmiany właściwości fizyczno-mechanicznych tych skał niż szok termiczny. 
Procesowi temu uległy zarówno gruboziarniste piaskowce - próbki z Czasławia, jak i średnioziarniste piaskowce z drugiego złoża. Jednak, jak wskazują wyniki badań laboratoryjnych, ta pierwsza odmiana była bardziej podatna na takie zmiany. Proces ten wywołał znaczący spadek prędkości fal ultradźwiękowych szczególnie w próbkach gruboziarnistych już po jego 10 powtórzeniach, natomiast w kolejnych cyklach następowało powierzchniowe wykruszanie ziaren próbek obu odmian i związany z tym ubytek masy. Po zakończonym męczeniu tą metodą (po 30 cyklach zamrozu) w piaskowcach gruboziarnistych obserwowano pod mikroskopem, zwłaszcza w kilkumilimetrowej zewnętrznej strefie, liczne pory, a nawet drobne spękania, których obecność ujawniała się w końcu w formie drobnych odspojeń materiału skalnego, głównie w narożach i krawędziach próbek.

Silniejszy wpływ zamrozu na zmiany właściwości próbek piaskowców gruboziarnistych z Czasławia należy wiązać przede wszystkim z faktem, że, przeważające w tej odmianie, proste i wklęsło-wypukłe kontakty ziaren kwarcu i skaleni bardziej sprzyjają obniżaniu wytrzymałości mechanicznej skały w tych miejscach niż kontakty zazębiające się. Ponadto niższy przyrost prędkości fal ultradźwiękowych w próbkach z Czasławia po nasyceniu ich wodą może wskazywać na większy stosunek ilości substancji ilastej do krzemionkowej w spoiwie w porównaniu z próbkami z drugiego złoża. Pęcznienie minerałów ilastych przyczynia się bowiem do osłabienia propagacji wygenerowanego impulsu. Charakter kontaktów międzyziarnowych i spoiwa ma zasadniczy wpływ na wytrzymałość omawianych piaskowców na niszczące działanie wody zamarzającej w przestrzeniach porowych.

Na zastosowany szok termiczny szybciej zareagowały próbki z Sobolowa, o czym świadczy znaczące obniżenie dla nich prędkości przebiegu fal ultradźwiękowych, zwłaszcza po pierwszych 10 cyklach. Prawdopodobnie tutaj również znaczącą rolę odgrywa sposób kontaktów - tym razem częściej zazębiających się. Ściślejsze połączenia, z jednej strony mocniejsze, sprzyjają jednocześnie powstawaniu większych naprężeń wywołanych rozszerzalnością temperaturową składników szkieletu i tym samym szybką reakcją skały, poprzez wywołanie pewnego rozluźnienia sztywnej struktury. To z kolei może prowadzić do osłabienia wpływu dalszych cykli ogrzewania i ochładzania, co potwierdzają wyniki prędkości fal uzyskane po 20 i 30 cyklach. Pozostałe badane parametry charakteryzował podobny poziom zmian dla obu odmian, aż do zakończenia męczenia (30 cykli).

Anizotropia badanych skał, potwierdzona pomiarami prędkości fal ultradźwiękowych w trzech wzajemnie prostopadłych kierunkach, wiąże się z ich teksturą. Pozioma laminacja wywołuje tłumienie impulsów w kierunku prostopadłym do niej (Figarska-Warchoł, Stańczak, 2016), w związku z tym dla tego właśnie kierunku (C) stwierdzono najniższą prędkość $\mathrm{w}$ piaskowcach gruboziarnistych. Z kolei próbki piaskowców z Sobolowa, w których obecne są rynnowe warstwowania przekątne, charakteryzuje najniższa prędkość $\mathrm{w}$ jednym $\mathrm{z}$ dwóch kierunków (B) równoległych do uławicenia. Opisane wyżej kierunki mogą być preferowane przez płaszczyzny osłabień i w konsekwencji spękań powstających w przyszłości w wyniku dalszego niszczenia próbek. Występowanie różnobarwnych lamin wpływa jednak zwykle na zwiększenie walorów estetycznych danego surowca, przez co materiał taki bywa ceniony i chętnie wykorzystywany przez projektantów, np. w zewnętrznych elewacjach budynków.

Analiza zjawisk pogodowych w Krakowie wykazała, że średnia temperatura okresów letnich sukcesywnie wzrasta od połowy lat $80 . \mathrm{XX}$ w., z niewielkimi odchyleniami od tego trendu. Sprzyja to zwiększaniu występowania niekorzystnych, gwałtownych zmian temperatury, związanych z burzami, jakie towarzyszą upalnym dniom. Obecnie szok termiczny, wywoływany przez takie zjawiska, staje się istotnym problemem, z jakim borykają się projektanci i wykonawcy kamiennych elementów budowlanych. Wynika to z ponad dwukrotnego wzrostu rocznej częstości cykli nagrzewania i chłodzenia kamieni w ostatnich 20 latach w stosunku do 2. połowy XX w., a także z nieustającej popularności tego materiału budowlanego. Jak się okazuje, wybór piaskowców istebniańskich jako materiału okładzinowego na południowe i zachodnie elewacje budynków, najbardziej narażonych na negatywny wpływ szoku termicznego, może być słuszny ze względu na stosunkowo słabą reakcję tego typu kamienia na niszczące działanie omawianego zjawiska. Powodem tego może być stosunkowo wysoka porowatość skały, ograniczająca destrukcyjny wpływ naprężeń składników mineralnych wywołanych zmianami temperatury. Nie bez znaczenia jest również jasna barwa badanych piaskowców, która obniża stopień pochłaniania energii promieniowania słonecznego.

Dla zim również zaobserwowano tendencję wzrostu średniej temperatury w ostatnich trzech dekadach, ale wahania w kolejnych latach siegają nawet kilku ${ }^{\circ} \mathrm{C}$. Dlatego w najbliższej przyszłości można nadal oczekiwać wystąpienia epizodów mroźnych i dość śnieżnych zim, a co za tym idzie wzmożenia wówczas destrukcyjnego wpływu zamrozu na te elementy piaskowcowe, które znajdują się w stanie zawilgocenia. Dotyczy to przede wszystkich elementów kamiennych zamontowanych przy gruncie, gdzie istnieje możliwość kapilarnego podsiąkania wilgoci, a także na północnych elewacjach budynków. Od tempa i dalszego kierunku zmian klimatycznych zależeć będzie liczba cykli zamrozu, na jakie w ciągu roku narażone będą badane piaskowce. Jej wyraźny spadek mógłby nastapić w dwóch przypadkach:

- dalszego wzrostu temperatur powietrza w okresie zimowym do poziomu, w którym liczba dni z temperaturą powietrza poniżej $0^{\circ} \mathrm{C}$ spadnie poniżej 50 ,

- powrotu mroźnych, ale krótkich zim, powodujących zamarzanie wody w porach skalnych na wiele dni bez możliwości jej topnienia.

Wydaje się, że obecnie bardziej prawdopodobny jest pierwszy scenariusz, choć celem niniejszej analizy nie było rozstrzygnięcie tego problemu.

Materiał kamienny użyty w przyziemnych partiach budynków w bezpośredniej bliskości chodników jest w dużej mierze narażony na działanie chlorku sodu stosowanego do odladzania nawierzchni chodnikowych. Spośród omawianych w pracy czynników wietrzenia, to mechaniczne oddziaływanie soli (krystalizacja), o wiele bardziej intensywne niż zamrozu (Wilczyńska-Michalik, 2004; Bromowicz, Figarska-Warchoł, 2010), jest tym, którego skutki mogą się zmniejszyć w nadchodzących latach. Sprzyjać temu będzie m.in. obniżająca się liczba dni z pokrywą śnieżną. $\mathrm{Z}$ danych Generalnej Dyrekcji Dróg Krajowych i Autostrad 
wynika, że zużycie soli w czasie zimowych sezonów lat 2016-2019 wynosiło w skali kraju ok. 252-376 tys. t, natomiast ostatnia zima z przełomu 2019/2020 spowodowała konieczność użycia ok. 154 tys. t soli. Jak widać złagodzenie klimatu spowodowało obniżenie ilości stosowanego chlorku sodu o połowę. Świadomość korozyjnego działania tej substancji i związanych z tym także zagrożeń ekologicznych wpływa również na zastępowanie jej, gdzie to możliwe, materiałami uszorstniającymi (np. piasek, żwir). Ponadto obecność roztworów innych soli wywołanych zanieczyszczeniami atmosfery może obniżać się w przyszłych latach ze względu na intensyfikację działań związanych z ograniczaniem emisji pyłów i gazów z pieców grzewczych i spalin samochodowych. Ostatnie trzy dekady przyniosły już wyraźne ograniczenie emisji wielu szkodliwych substancji pochodzących z sektora przemysłowego.

\section{WNIOSKI}

1. Przeprowadzone badania wykazały, że odporność piaskowców istebniańskich na atmosferyczne czynniki niszczące zależy od wielkości i obtoczenia ich składników, a także rodzaju kontaktów międzyziarnowych. Istotna jest także ilość i skład spoiwa. Różnice w nasiąkliwości poszczególnych odmian mieszczące się $\mathrm{w}$ granicach $1 \%$ mają drugorzędne znaczenie.

2. Próbki gruboziarnistych piaskowców z Czasławia wykazują oznaki zniszczenia w skali makro i mikro już po 20 cyklach zamrozu, podczas gdy średnioziarniste piaskowce z Sobolowa zmieniają się nieznacznie dopiero po 30 cyklach. Obydwie odmiany okazały się dość odporne na szok termiczny. Jego wpływ został wykazany zasadniczo poprzez pomiary prędkości fal ultradźwiękowych.

3. Stwierdzone od połowy lat 80 . XX w. zmiany klimatu Krakowa wpływają na intensyfikację oddziaływania latem szoku termicznego, przy jednoczesnym możliwym osłabieniu destrukcyjnego wpływu zamrozu i soli, stosowanej do odladzania dróg i chodników, na piaskowcowe elementy architektoniczne.

4. Wybór piaskowców istebniańskich jako materiału okładzinowego na południowe i zachodnie elewacje budynków może być odpowiedni ze względu na stosunkowo słabą reakcję tego typu kamienia na niszczące działanie naprężeń wywoływanych nagłymi zmianami temperatury skały.

Autorki pragną złożyć szczere podziękowania Recenzentom za wysiłek włożony w analizę tekstu oraz cenne uwagi, które podniosły wartość merytoryczną artykułu. Praca finansowana z subwencji Ministerstwa Nauki i Szkolnictwa Wyższego dla AGH w Krakowie (nr 16.16.140.315) oraz funduszy na badania statutowe Instytutu Gospodarki Surowcami Mineralnymi i Energią PAN w $2020 \mathrm{r}$.

\section{LITERATURA}

BROMOWICZ J. 2001 - Ocena możliwości wykorzystania skał z okolic Krakowa do rekonstrukcji kamiennych elementów architektonicznych. Gosp. Sur. Min., 17 (1): 5-73.

BROMOWICZ J., FIGARSKA-WARCHOŁ B. 2010 - Raport z badań nad zmianami właściwości skał wywołanych zamrozem. Pr. Nauk. Inst. Górn. PWr., Stud. Mat., 130 (37): 41-55.

BROMOWICZ J., MAGIERA J. 2015 - Kamienie wczesnośredniowiecznych budowli Krakowa: ich pochodzenie na tle geologii miasta. Wyd. AGH, Kraków.

BURTAN J. 1956 - Szczegółowa Mapa Geologiczna Polski w skali $1: 50$ 000, ark. Wieliczka. Inst. Geol., Warszawa.

CIESZKOWKI M., WAŚKOWSKA A. 2010 - Zamki znad jezior Rożnowskiego i Czchowskiego jako geoturystyczne lapidaria i rola piaskowców istebniańskich w ich powstaniu. Geoturystyka, 2 (21): 3-18. FIGARSKA-WARCHOŁ B., STAŃCZAK G. 2016 - Ocena mikrostruktur kierunkowych i ich znaczenie dla właściwości technicznych piaskowców. Górn. Odkryw., 57 (4): 26-38.

HALSEY D.P., MITCHELL D.J., DEWS S.J. 1998 - Influence of climatically induced cycles in physical weathering. Quart. J. Eng. Geol., 31: 359-367.

KITA-BADAK M. 1963 - O możliwości wykorzystania piaskowców warstw istebniańskich z okolic Dobczyc. Kwart. Geol., 7: 374-383.

KSIĄŻKIEWICZ M. 1951 - Objaśnienia do arkusza Wadowice, $1: 50$ 000. Inst. Geol., Warszawa.

PESZAT C. (red.) 1976 - Piaskowce karpackie, ich znaczenie surowcowe i perspektywy wykorzystania. Zesz. Nauk. AGH, Geologia, 2 (2): 27-35.

PESZAT C., BUCZEK-PUŁKA M. 1984 - Zmienność właściwości fizyczno-mechanicznych budowlanych piaskowców istebniańskich obszaru Karpat. Zesz. Nauk. AGH, Geologia, 10 (1): 5-34.

PESZAT C., WIESER T. 1999 - Mineral composition of matrix in thick-bedded Istebna Sandstones (The Polish Flysch Carpathians). Mineral. Pol., 30 (1): 73-84.

PN-EN 1936:2010 - Metody badań kamienia naturalnego. Oznaczanie gęstości i gęstości objętościowej oraz całkowitej i otwartej porowatości. PN-EN 13755:2008 - Metody badań kamienia naturalnego. Oznaczanie nasiąkliwości przy ciśnieniu atmosferycznym.

PN-EN 12371:2010 - Metody badań kamienia naturalnego. Oznaczanie mrozoodporności.

PN-EN 14066:2013-07 - Metody badań kamienia naturalnego. Oznaczanie odporności na starzenie spowodowane szokiem termicznym.

PN-EN 14579: 2005 - Metody badań kamienia naturalnego. Oznaczanie prędkości rozchodzenia się dźwięku.

RAJCHEL J. 2005 - Kamienny Kraków. Spojrzenie geologa. Wyd. AGH, Kraków.

REMBIŚ M., SMOLEŃSKA A. 2010 - Odporność wybranych piaskowców karpackich na krystalizację soli i zmiany ich mikrostruktur. Gosp. Sur. Min., 26 (1): 37-59.

ROBERTSON E.C. 1988 - Thermal properties of rocks. United States Department of the Interior, Geological Survey, Open File Report, 88-441: 1-106.

SMOLEŃSKA A., KORZENIOWSKI M., OZGA P. 2010 - Kamień budowlany i dekoracyjny zamku Kmitów i Lubomirskich w Nowym Wiśniczu. Prz. Geol., 58 (10): 984-990.

UNRUG R. 1963 - Istebna beds - a fluxoturbidity formation in the Carpathian flysch. Rocz. PTG, 33 (1): 49-92.

WILCZYŃSKA-MICHALIK W. 2004 - Influence of atmospheric pollution on the weathering of stones in Cracow monuments and rock outcrops in Cracow, Cracow-Częstochowa Upland and the Carpathians. Wyd. Nauk. Akad. Pedagog., Kraków.

WILCZYŃSKA-MICHALIK W., MICHALIK M. 1995 - Deterioracja materiałów skalnych w budowlach Krakowa. Prz. Geol., 43: 227-235.

Praca wpłynęła do redakcji $5.12 .2020 \mathrm{r}$.

Akceptowano do druku 19.01.2021 r. 


\section{Wpływ długotrwałego oddziaływania cyklicznych zjawisk atmosferycznych na właściwości piaskowców istebniańskich (patrz str. 109)}

The influence of long-term cyclic atmospheric phenomena on the Istebna sandstone properties (see p. 109)

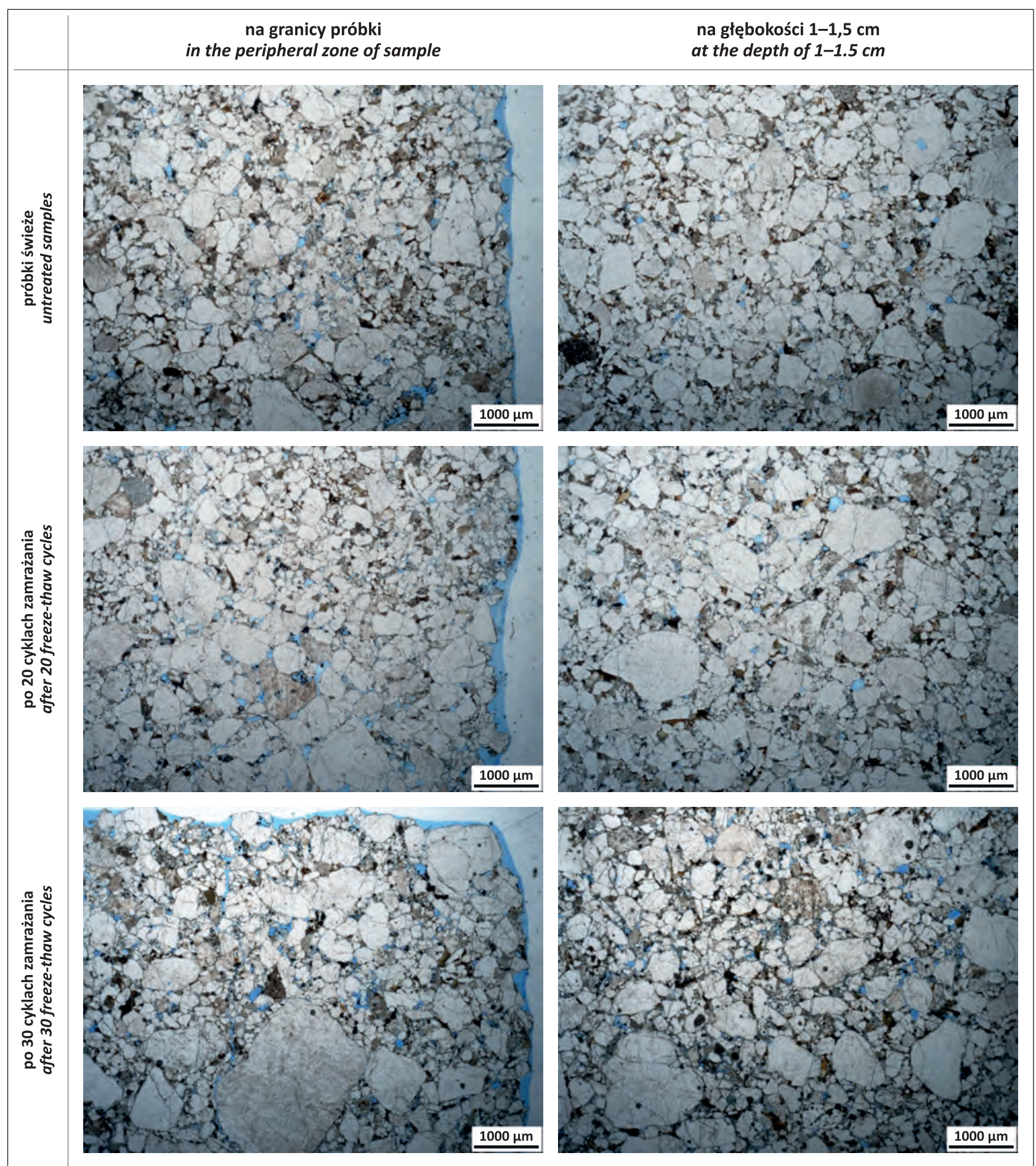

Ryc. 5. Obrazy mikroskopowe próbek piaskowca istebniańskiego ze złoża Czasław poddanych procesowi zamrażania i rozmrażania. Porowatość podkreślona niebieską barwą żywicy. Polaryzatory równoległe

Fig. 5. Microphotographs of the Istebna sandstones from the Czasław deposit after their freezing and thawing. Porosity of samples is expressed in blue resin. Transmitted light, one polarizer 